\title{
Patient's Perceptions and Attitude toward Medications in Saudi Arabia
}

\author{
Yousef Ahmed Alomi ${ }^{1, *}$, Dima Ahmad Alaskari², Malak Mohammad Almelfi², Dima Ali Badawi ${ }^{3}$, \\ Abdullah Mohammad Alshihri ${ }^{4}$ \\ ${ }^{1}$ The Past General Manager of General Administration of Pharmaceutical Care and The Past Head, National Clinical pharmacy \\ and pharmacy practice and Pharmacy $R$ and D Administration, Ministry of Health, Riyadh, SAUDI ARABIA. \\ ${ }^{2}$ General Administration of Pharmaceutical Care, Ministry of Health, Riyadh, SAUDI ARABIA. \\ ${ }^{3}$ Pharmaceutical Care Services, Saudi Germany Hospital, Aseer, SAUDI ARABIA. \\ ${ }^{4}$ Head, Pharmaceutical Care Services, Abha Maternity and Children Hospital, Abha, SAUDI ARABIA.
}

\section{Received: 02 June 2018; \\ Accepted: 28 August 2018 \\ *Correspondence to: \\ Dr. Yousef Ahmed Alomi,}

The Past General Manager of General Administration of Pharmaceutical Care, The Past Head, National Clinical pharmacy and pharmacy practice The Past Head, Pharmacy $R$ and D Administration Ministry of Health, P.O.BOX 100, Riyadh 11392, Riyadh, SAUDI ARABIA.

Email: yalomi@gmail.com

Copyright: (C) the author(s),publisher and licensee Indian Academy of Pharmacists. This is an open-access article distributed under the terms of the Creative Commons Attribution Non-Commercial License, which permits unrestricted non-commercial use, distribution, and reproduction in any medium, provided the original work is properly cited.

\begin{abstract}
Objective: To explore the Patients perceptions and attitudes toward Medications in Saudi Arabia. Methods: It is a 4-months cross-sectional survey of patient and basic knowledge of medicines. The survey consisted of two-part, demographic information and second part forty-nine questions divided into four domains. It included domain 1: Primary or essential information about patient medication, domain 2: patient information about the drug-related problem, domain 3: patient information about drug-related cost and domain 4: patient perception of medications. Medline Plus health information and Daily Med-INH elements information from National Institute of Health United State of America were used. The 5-point Likert response scale system was used. The questions were open and closed-ended. The survey distributed through social media and at 500-bed pediatrics and maternity hospital in Asir region, at ambulatory care pharmacy. The authors did the patients interview with electronic survey documentation. The survey was made in an electronic format and it analyzed domain four patient perception of medications through survey monkey system. Results: The total responders were (614) Saudi patient. The gender distribution 523 (86.7\%) were females and $91(13.3 \%)$ were males. The type of medication used was for Diabetes, Hypertension, Skin and Respiratory diseases. More than half of responders sometimes had difficulties in reading drug name $374(61.6 \%)$ and $126(20.8 \%)$ cannot know the expiration date of Medications. The responders showed that $207(34 \%)$ takes their medication without any prior information, 276 (45.44\%) described drug to the person had the same disease and $325(53.8 \%)$ use the medication without any prescription. Also; 328 (53.3\%) of responders stopped their medication when they feel better and 274 (44.9\%) of them they completed entire medication course of therapy. The responders displayed that 310 (50.9\%) believed that Drug Information given by health care was not enough and 238 (39.3\%) of responders thought that their medication knowledge was not sufficient. Conclusion: There were a wrong perception and attitudes toward medications. It may lead to diseases progress, not a useful medicine and occurrence of drug-related morbidity and mortality. Global and general improvement in understanding of medications knowledge through patient counseling is mandatory.

Key word: Patient, Perceptions, Attitudes medications, Ministry of health, Saudi Arabia.
\end{abstract}

\section{INTRODUCTION}

The management of illness needs to complete the cycle of healthcare plan and management. The essential part of this plan is taking medications. The background of the patient is an influential factor in the Patients attitude toward his/her medications, with the rapidly rising level of education, awareness of population health has increased. The development of the Internet and smart devices has made easy access to medical data and disease treatment methods through various channels. Some patient stated that they does not complete the treatment and wishes not to take the medication at all. Some patients under treatment not take the optimal dose or not complete the management duration. Other, they over treated and took a high dose for an extended period that may leads to toxicity. Some patient had positive perception and other had a negative perception. Some patient prescribed medication to her or his Neighbors, other does not take any medication because they are chemical and prefer to natural and herbal medications.
Patient's knowledge of medication use is not only of vital importance in the prevention of drug-related problems but also a significant factor that influences treatment success and hence if provided; it offers an opportunity for one to attain a full health potential. ${ }^{[1]}$ When a patient uses the right medication in the wrong way, his condition is likely to worsen. Patient's Awareness, Attitude, Understanding and Perceptions towards the medications are vital in the desired drug response. Patients often want to obtain diverse information about their condition and discuss their illnesses and treatment with doctors. Several international studies have conducted to explore the patient's perception of medications which varies between excellent or lousy perception, attitudes and behaviors. ${ }^{[2-8]} \mathrm{Few}$ local studies explored the perception of medications, in particular, situations. ${ }^{[9]}$ Most of the studies had limited number of patients and measures particular medications. Also, it is hard to find local, Gulf of Middle East countries investigated the patient attitudes toward the medications. The goal of the study was to explore the 
patient's perception about medications in Kingdom of Saudi Arabia.

\section{METHODS}

It is a 4-months cross-sectional survey of patient and basic knowledge of medicines. The survey consisted of two-part, demographic information and second part forty-nine questions divided into four domains. It included domain 1: Primary or essential information about patient medication, domain 2: patient information about the drug-related problem, domain 3: patient information about drug-related cost and domain 4: patient perception of medications. Medline Plus health information and DailyMed-INH elements information from National Institute of Helath United State of America were used. ${ }^{[10-11]}$ The 5 -point Likert response scale system was used. The questions were open and closed-ended. The survey was distributed through social media and at 500-bed pediatrics and maternity hospital in Asir region, at ambulatory care pharmacy. The hospitals were accredited by Saudi Center for Healthcare organization (CBAHI) and Joint Commission on Hospital Accreditation from United State of America (USA). ${ }^{[2-13]}$ The hospital's several departments were included such as Pediatrics, Obstetrics and Gynecology. It had Adults, Pediatrics and Neonatal critical care, with the separated nursing unit. In addition to medical and surgical sections for adults, pediatrics and neonates. The pharmacy departments distributed the medication through unit dose system according to CBAHI standards and American Society of Health-System standards. Also, the pharmacy had inpatient pharmacy, outpatient pharmacy, Intravenous Admixture services with professional Total Parenteral Nutrition. The clinical pharmacy services did not entirely exist except some programs for an instant; drug information center, patient-counseling services and medication safety program. The authors did the patients interview with electronic survey documentation. The survey was made in an electronic format and it analyzed domain four patient perception of medications through survey monkey system.

\section{RESULTS}

The total responders were (614) patients with Saudi $564(96.1 \%)$ and Non-Saudi $23(3.9 \%)$ nationalities. The gender distribution $523(85.2 \%)$ were females and $91(14.8 \%)$ were males. The majority of them in age (18-44) 78.3\% and located at Asir region 325 (52.93\%) and Riyadh region 163 (26.54\%). The most patients had the Bachelor Degree 311 (50.65\%) followed by High school 138 (22.48\%) and Diploma 47 (7.65\%). The most type of medications used was anti-diabetic and anti-hypertension medicines, Skin medications and drugs for Respiratory Diseases. Also, the total patient currently taking medication were 249 (43.23\%). Of those the most number of medication taken either one 96 (38.55\%), two medications $79(31.73 \%)$, three medications $25(10.04 \%)$ and four medications 24 $(10.04 \%)$ as explored in Table 1 . More than half of responders sometimes had difficulties in reading drug name 374 (61.6\%) and $126(20.8 \%)$ cannot know the expiration date of Medications. The responders showed that 207 (34\%) takes their medication without any prior information, $276(45.44 \%)$ described drug to the person had the same disease and $325(53.8 \%)$ use the medication without a prescription. Also; 328 (53.3\%) of responders stopped their medication when they feel better and $274(44.9 \%)$ of them they completed entire medication course of therapy. The responders displayed that $310(50.9 \%)$ believed that Drug Information given by health care was not enough and $238(39.3 \%)$ of responders thought that their medication knowledge was not sufficient as explored in Table 2.

\section{DISCUSSION}

The medications become more efficient in relieving/healing illnesses and improving patients' health condition. The demand for medication-related information increases in line with patients' enhanced expectations of what should provide. Patients are entitled to education on proper medication
Table 1: Demographic responder qualifications information.

\begin{tabular}{|c|c|c|}
\hline Characteristics & Response N & Response \% \\
\hline \multicolumn{3}{|l|}{ Sex } \\
\hline Female & 523 & $85.2 \%$ \\
\hline Male & 91 & $14.8 \%$ \\
\hline Answered question & 614 & $100 \%$ \\
\hline Skipped question & 0 & \\
\hline \multicolumn{3}{|l|}{ Nationality } \\
\hline Saudi & 564 & $96.1 \%$ \\
\hline Non-Saudi & 23 & $3.9 \%$ \\
\hline Answered question & 587 & $100 \%$ \\
\hline Skipped question & 27 & \\
\hline \multicolumn{3}{|l|}{ Age } \\
\hline$<18$ & 34 & $9.9 \%$ \\
\hline $18-29$ & 267 & $103.0 \%$ \\
\hline $30-44$ & 214 & $60.9 \%$ \\
\hline $45-59$ & 87 & $22.5 \%$ \\
\hline $60+$ & 12 & $3.6 \%$ \\
\hline Answered question & 614 & $100 \%$ \\
\hline Skipped question & 0 & \\
\hline \multicolumn{3}{|l|}{ Total Experiences } \\
\hline Doctorate degree & 7 & $1.14 \%$ \\
\hline Master degree & 17 & $2.77 \%$ \\
\hline Bachelor Degree & 311 & $50.65 \%$ \\
\hline Diploma & 47 & $7.65 \%$ \\
\hline High school & 138 & $22.48 \%$ \\
\hline Intermediate School & 33 & $5.37 \%$ \\
\hline Primary School & 27 & $4.40 \%$ \\
\hline Not educated & 34 & $5.54 \%$ \\
\hline Answered question & 614 & $100 \%$ \\
\hline Skipped question & 0 & \\
\hline \multicolumn{3}{|l|}{ The current medications } \\
\hline Diabetic Medication & 79 & $12.91 \%$ \\
\hline Antihypertensive Medication & 64 & $10.46 \%$ \\
\hline Cardiac Medication & 13 & $2.12 \%$ \\
\hline Asthma Medication & 50 & $8.17 \%$ \\
\hline Derma Medication & 57 & $9.31 \%$ \\
\hline Anti-Rheumatic & 32 & $5.23 \%$ \\
\hline Do not take anything now & 412 & $67.32 \%$ \\
\hline Others & 87 & $14.22 \%$ \\
\hline Answered question & 612 & $100 \%$ \\
\hline Skipped question & 2 & \\
\hline \multicolumn{3}{|c|}{ Number of current medication taken } \\
\hline Nothing & 327 & $56.77 \%$ \\
\hline 1 & 96 & $38.55 \%$ \\
\hline 2 & 79 & $31.73 \%$ \\
\hline 3 & 25 & $10.04 \%$ \\
\hline 4 & 24 & $9.64 \%$ \\
\hline 5 & 13 & $5.22 \%$ \\
\hline 6 & 5 & $2.01 \%$ \\
\hline 7 & 3 & $1.20 \%$ \\
\hline 8 & 0 & $0.00 \%$ \\
\hline 9 & 1 & $0.40 \%$ \\
\hline 10 & 2 & $0.80 \%$ \\
\hline more than 10 & 0 & $0.00 \%$ \\
\hline Answered question & 576 & \\
\hline Skipped question & 38 & \\
\hline
\end{tabular}


Alomi, et al.: Study about Patient's Perceptions and attitude toward Medications

Table 2: The Patient Perception about Medications.

\begin{tabular}{|c|c|c|c|c|c|c|c|c|c|}
\hline No & Perceptions Inquiries & $\begin{array}{l}\text { Response } \\
\text { Count }\end{array}$ & $\begin{array}{l}\text { Response } \\
\text { Percent }\end{array}$ & $\begin{array}{l}\text { Response } \\
\text { Count }\end{array}$ & $\begin{array}{l}\text { Response } \\
\text { Percent }\end{array}$ & $\begin{array}{l}\text { Response } \\
\text { Count }\end{array}$ & $\begin{array}{l}\text { Response } \\
\text { Percent }\end{array}$ & $\begin{array}{l}\text { answered } \\
\text { question }\end{array}$ & $\begin{array}{l}\text { skipped } \\
\text { question }\end{array}$ \\
\hline & & \multicolumn{2}{|l|}{ Always } & \multicolumn{2}{|l|}{ Sometimes } & \multicolumn{2}{|l|}{ Never } & & \\
\hline 1 & $\begin{array}{l}\text { Are you having difficulty } \\
\text { reading the name of } \\
\text { your medicine }\end{array}$ & 76 & $12.52 \%$ & 374 & $61.61 \%$ & 157 & $25.86 \%$ & 607 & 7 \\
\hline \multirow[t]{2}{*}{2} & $\begin{array}{l}\text { Do you avoid going to the } \\
\text { hospital expected symptoms } \\
\text { would subside? }\end{array}$ & 136 & $22.41 \%$ & 404 & $66.56 \%$ & 67 & $11.04 \%$ & 607 & 7 \\
\hline & & \multicolumn{2}{|l|}{ Yes } & \multicolumn{2}{|l|}{ No } & \multicolumn{2}{|l|}{ Others } & & \\
\hline 3 & $\begin{array}{l}\text { Can you read the expiration } \\
\text { date printed on the medication }\end{array}$ & 461 & $76.07 \%$ & 126 & $20.79 \%$ & 19 & $3.14 \%$ & 606 & 8 \\
\hline 4 & $\begin{array}{l}\text { Do you believe that the drug } \\
\text { information given by healthcare } \\
\text { professionals enough }\end{array}$ & 274 & $45.07 \%$ & 310 & $50.99 \%$ & 25 & $4.11 \%$ & 608 & 5 \\
\hline 5 & $\begin{array}{l}\text { Do you feel that your } \\
\text { knowledge of prescribed } \\
\text { medications for you is good } \\
\text { enough? }\end{array}$ & 351 & $57.92 \%$ & 238 & $39.27 \%$ & 21 & $3.47 \%$ & 606 & 8 \\
\hline 6 & $\begin{array}{l}\text { Have you ever tackled a drug } \\
\text { you do not have any prior } \\
\text { information about }\end{array}$ & 207 & $34.16 \%$ & 391 & $64.52 \%$ & 10 & $1.65 \%$ & 606 & 8 \\
\hline 7 & $\begin{array}{l}\text { Is it possible to describe } \\
\text { another drug to a person } \\
\text { suffering from the same } \\
\text { illness? }\end{array}$ & 276 & $45.54 \%$ & 315 & $51.98 \%$ & 15 & $2.48 \%$ & 606 & 8 \\
\hline \multirow[t]{2}{*}{8} & $\begin{array}{l}\text { Is it possible to use a drug } \\
\text { without a prescription? }\end{array}$ & 325 & $53.81 \%$ & 258 & $42.72 \%$ & 21 & $3.48 \%$ & 604 & 10 \\
\hline & & \multicolumn{2}{|c|}{ Take the entire course } & \multicolumn{2}{|c|}{$\begin{array}{l}\text { Stop when you feel } \\
\text { better }\end{array}$} & \multicolumn{2}{|l|}{ Others } & & \\
\hline 9 & $\begin{array}{l}\text { Do you take the entire course } \\
\text { or you just stop the medication } \\
\text { when you feel better }\end{array}$ & 274 & $44.92 \%$ & 328 & $53.77 \%$ & 8 & $1.31 \%$ & 610 & 4 \\
\hline
\end{tabular}

use; not only by their humanity but also by the fact that the effect of the medication (whether therapeutic, side effects, etc.) felt by the patients. ${ }^{[2]}$ The patients with desired outcomes were more likely to use the drug again and were more aware of taking it on time. Patient with any difficulties in understanding the use and times of use tend to abandon the medicine, especially if the symptoms are mild. Full clarification of the patient about how to use the drug what happens in his/her body and clarify the side effects of the drug affects the patient's perceptions and attitude. Health factors were strongly related to knowledge and adherence. The participants with better health status reported that higher knowledge and adherence patients who took fewer medications were less adherent, and Feeling ill appears to be a barrier to adherence. ${ }^{[3]}$ Medication knowledge (e.g., knowing the name of the medication, dosage, how to take it, etc.) is also highly correlated with medication adherence. ${ }^{[4]}$ Several pharmacy practices started in the early 2010s to improve the pharmaceutical care services to offers the best care to the patients. ${ }^{[14]}$ Several pharmacy programs organized to provide drug information and correct any wrong attitudes or perception of the patient. The famous program at Ministry of Health provided by the pharmacist was answering drug inquiries calling system through hotline (937). On a daily basis over $24 / 7$, the pharmacist answers to drug information requests from the patients. ${ }^{[15]}$ Also, the patient medications counseling program during patient discharge or at outpatient pharmacy or Ambulatory care medications counseling clinics. ${ }^{[16]}$ The investigator wishes to explore the actual patient perception or behavior toward the medication. The finding of the study showed the half of the patients had lousy impression or perception of the medications. More than half had difficulty in reading drug name or expiry date of medications although most of the responders were at a young age with University education level and expected to know the English language. Nevertheless, in reality not so. Because of lousy health education during school age and week health education for the public, the results of difficulties in the reading of drug name better than what reported by Perera T. et al. maybe because most of the country's population are not speaking very well in the English language, the finding of perception reading expiry date of medication could not compare with other studies because it was not investigated. ${ }^{[17]}$ The finding showed one-third of the responders use medications without any information and almost half of the patients prescribed the medications to their friend or family expected the same disease without official diagnosis and prescriptions. That is related to dial with medications as look like as food or cosmetic without any health information that has led to progression of disease or complications or appear of drug-related problems with the patients. That is a complication to visit hospitals or admission or fealty and high economic burden on the healthcare system. The finding of the described drug to the person had the same disease is higher than that reported by Aishwaryalakshmi, $\mathrm{K}$ et al. ${ }^{[3]}$ Because of our subject had lower health education than them, the other results of takes their medication without any prior information or use the medication without a prescription could not compare it with other results because it not investigated. The half of patient does not complete their duration of therapy and stop the medications by them self, that may lead to non-excellent treatment of disease and may cause the resistance of microorganisms if they used antibiotics. It may lead to the high complications of disease and the high cost of disease management. That is what resembles what reported by Aishwaryalakshmi, $\mathrm{K}$ et al. ${ }^{[3]}$ The half of patients stated previous lousy perception related to week health education by healthcare 
professionals and their medications knowledge is enough for appropriate drug therapy. That is what resembles what reported by Aishwaryalakshmi, $\mathrm{K}$ et al..$^{[3]}$ That is expected because patient counseling newly established at Ministry of Health organizations and patient medications education is not mandatory by law while dispensing medications at community pharmacies.

\section{CONCLUSION}

Regarding patient's knowledge of medications, there is a wrong perception and attitudes toward drugs. It may lead to diseases progress, not a useful medicine and occurrence of drug-related morbidity and mortality. Improvement in understanding of medications knowledge through patient counseling is mandatory.

\section{ACKNOWLEDGMENT}

None.

\section{CONFLICT OF INTEREST}

None.

\section{ABBREVIATION}

KSA: Kingdom of Saudi Arabia MOH: Ministry of Health; CBAHI: Saudi Center for Accreditation of Healthcare Institutions.

\section{REFERENCES}

1. Ssemaluulu R, Adome R. Patients' knowledge of medication use as an equity issue in health care: Do health workers pay attention to this?. 2006. Available from: http://www.equinetafrica.org/sites/default/files/uploads/documents/ CBP3EHSadome.pdf

2. AI-Qazaz HK, Hassali MA, Shafie AA, Syed SSA, Sundram S. Perception and knowledge of patients with type 2 diabetes in Malaysia about their disease and medication: A qualitative study. Res Soc Adm Pharm. 2011;7(2):180-91.

3. Aishwaryalakshmi K, Sasikala B, Sreelalitha N, Vigneshwaran E, Yr P.
Assessment of Knowledge Perception and Attitudes on Medications in General Population. Indian J Pharm Pract.2012;5(3):3-6.

4. Lau DT, Briesacher BA, Mercaldo ND, Halpern L, Osterberg EC, Jarzebowski $\mathrm{M}$, et al. Older patients' perceptions of medication importance and worth: An exploratory pilot study. Drugs and Aging. 2008;25(12):1061-75.

5. Schwappach DLB, Wernli M. Chemotherapy Patients' Perceptions of Drug Administration Safety. J Clin Oncol. 2010;28(17):2896-901.

6. Shah S, Akbari M, Vanga R, Kelly CP, Hansen J, Theethira T, et al. Patient perception of treatment burden is high in celiac disease compared with other common conditions. Am J Gastroenterol. 2014;109(9):1304-11.

7. Cassell B, Gyawali CP, Kushnir VM, Gott BM, Nix BD, Sayuk GS. Beliefs About GI Medications and Adherence to Pharmacotherapy in Functional GI Disorder Outpatients. Am J Gastroenterol. 2015;110(10):1382-7.

8. Stuart AV, Gupta MM, Sealy P. Patients' Perception of Generic Drugs at Health Institutions in Trinidad and Tobago. J Young Pharm. 2017;9(3):362-6.

9. Zaki NM, Albarraq AA. Use, attitudes and knowledge of medications among pregnant women: A Saudi study. Saudi Pharm J. 2014;22(5):419-28.

10. MedlinePlus - Health Information from the National Library of Medicine. Available from: https://medlineplus.gov/

11. DailyMed. Available from: https://dailymed.nlm.nih.gov/dailymed/

12. Medication Management (MM). In: National Hospital Standards. $2^{\text {nd }}$ Ed. Saudi Central Board for Accreditation of Healthcare Institutions. 2015;194-211.

13. Comprehensive Accreditation Manuals. Joint Commission Resources. Available from: http://www.jcrinc.com/store/publications/manuals/

14. Alomi YA. National Pharmacy Practice Programs at Ministry of Health in Saudi Arabia. JPharm Pharm Sci. 2015;1(2):17-8.

15. Alomi YA, Mudaiheem HA, Alsharfa A, Albassri H, Alonizi K, et al. National Drug Information Center Services through Ministry of Health Hotline Calling Center (937) in Saudi Arabia. Adv Pharmacoepidemiol Drug Saf. 2016;5(198).

16. Alomi YA. National Pharmacy Administration Programs at Ministry of Health in Saudi Arabia. BAOJ Pharm Sci. 2015;1(9).

17. Perera T, Ranasinghe P, Perera U, Perera S, Adikari M, Jayasinghe S, et al. Knowledge of prescribed medication information among patients with limited English proficiency in Sri Lanka. BMC Res Notes. 2012;5(1):658.

Cite this article as: Alomi YA, Alaskari DA, Almelfi MM, Badawi DA, Alshihri AM. Patient's Perceptions and Attitude toward Medications in Saudi Arabia. J Pharm Pract Community Med. 2018;4(3):187-90. 